\title{
ЗМІНИ ГІСТОЛОГІЧНОЇ БУДОВИ ПЕЧІНКИ ЩУРІВ ЗА УМОВ ТЕТРАХЛОРМЕТАНОВОГО ГЕПАТИТУ ТА КОРЕКЦІЇ ГУСТИМ ЕКСТРАКТОМ ІЗ ЛИСТЯ ШОВКОВИЦІ ЧОРНОї
}

\author{
๑). І. Герасимець

\section{Тернопільський державний медичний університет імені І. Я. Горбачевського}

\begin{abstract}
Резюме: проведено гістологічне вивчення впливу густого екстракту з листя шовковиці чорної на перебіг вільнорадикальних процесів у печінці щурів, уражених тетрахлорметаном. Встановлено, що під впливом досліджуваного фармакологічного препарату зменшуються порушення гістологічної структури печінки, які виникають при гострому тетрахлорметановому гепатиті.
\end{abstract}

Ключові слова: густий екстракт, листя шовковиці чорної, гепатопротекторні властивості, тетрахлорметановий гепатит.

Вступ. Токсичні гепатити становлять серйозну медичну та соціальну проблему через широку розповсюдженість, а також високий ризик розвитку невиліковних захворювань печінки $[1,2,3]$.

Розробка патогенетично обґрунтованих методів лікування токсичних гепатитів належить до актуальних проблем сучасності. Це зумовлено невпинним ростом частоти гострих отруєнь, які переважно виникають в осіб працездатного віку $[3,4,5,6]$.

Одним із основних завдань сучасної фармації $€$ створення нових лікарських засобів, які б мали високу ефективність при незначній токсичності або ж при ії відсутності. Значну увагу науковці приділяють вивченню лікарських рослин 3 метою створення на їх основі препаратів та біологічно активних добавок, що знайшли б своє застосування в офіцинальній медицині $[7,8,9,10]$.

Об'єкт наших досліджень - листя шовковиці чорної. Проведений нами аналіз літературних джерел показав, що дану рослинну сировину можна рекомендувати до використання як джерело флавоноїдів, вітамінів С та Р для подальшого створення на їх основі субстанцій $з$ антиоксидантними та гепатопротекторними властивостями [11, 12]. Тому ми вирішили апробувати коригуючі властивості густого екстракту з листя шовковиці чорної на моделі токсичного ураження печінки тетрахлорметаном, який є класичною гепатотропною отрутою [13, 14].

Результати проведених нами дослідження показали, що густий екстракт з листя шовковиці (ГЕЛШ) проявляє виражену стабілізуючу дію на плазматичні та цитоплазматичні мембрани, нормалізує процеси перекисного окиснення ліпідів (ПОЛ) в організмі уражених тварин, чинить позитивний вплив на активність ферментів анти- оксидантного захисту (АОЗ) [15, 16, 17]. Це дозволяє стверджувати, що досліджуваний середник проявляє виражені антиоксидантні та гепатопротекторні властивості за умов токсичного гепатиту, викликаного $\mathrm{CCl}_{4}$.

Для підтвердження отриманих результатів ми провели гістологічне дослідження структури печінки за умов гострого $\mathrm{CCl}_{4}$ гепатиту та після корекції порушень екстрактом з листя шовковиці та корвітином.

Метою даного роботи було з'ясування змін гістологічної структури печінки при її гострому ураженні тетрахлоретаном та корекції викликаних порушень ГЕЛШ.

Методи дослідження. Гострий токсичний гепатит моделювали за допомогою внутрішньошлункового введення 50 \% олійного розчину $\mathrm{CCl}_{4}$ у дозі 1,0 мл/кг маси тварини $[13,14]$. Евтаназію проводили з використанням тіопенталу натрію на 4-ту та 7-му доби після введення тетрахлорметану. Дослідженням піддавали гомогенат печінки, цільну кров та сироватку крові. Кров забирали із серця тварин.

При вивченні гепатопротекторної та антиоксидантної активності досліджуваної субстанції як препарат порівняння використовували “Корвітин" (виробництва ЗАТ НВЦ "Борщагівський хіміко-фармацевтичний завод", м. Київ) лікарський засіб з антиоксидантною активністю. Значення дози препарату порівняння обирали, спираючись на інструкцію до застосування та використовуючи коефіцієнти видової чутливості Ю. Р. Риболовлєва і його метод перерахунку дози для людини на дозу для щура [18]. Умовнотерапевтична доза для щура становить 42 мг/кг. Корвітин вводили внутрішньовенно. Екстракт шовковиці тваринам вводили інтрагастрально.

ISSN 2312-0967. Pharmaceutical review. 2015. № 1 
Pharmacological researches of biologically active substances

В експерименті використано 42 статевозрілих нелінійних щури-самці масою 160-180 г, яких розділили на 7 груп по 6 тварин у кожній. Всі піддослідні тварини були поділені на такі групи: 1-ша - інтактні щури; 2-га - тварини, отруєні $\mathrm{CCl}_{4}$, 4-та доба - дослідження; 3-тя - тварини, отруєні $\mathrm{CCl}_{4}$, 7-ма доба експерименту; 4-та - уражені $\mathrm{CCl}_{4}$ тварини, яким щоденно вводили 150 мг/кг ГЕЛШ, 4-та доба дослідження; 5-та - уражені $\mathrm{CCl}_{4}$ тварини, яким щоденно вводили 150 мг/кг ГЕЛШ, 7-ма доба експерименту; 6-ма - уражені $\mathrm{CCl}_{4}$ тварини, яким вводили корвітин в дозі 42 мг/кг маси, 4-та доба дослідження; 7-та - уражені $\mathrm{CCl}_{4}$ тварини, яким вводили корвітин в дозі 42 мг/кг маси, 7-ма доба експерименту.

Для гістологічних досліджень брали печінку піддослідних тварин на 4-ту та 7-му доби розвитку гепатиту та після корекції екстрактом 3 листя шовковиці та корвітином у відповідні доби.

Зразки органу фіксували в 10 \% розчині формаліну, дегідратували у спиртах зростаючої концентрації та заливали у целоїдин-парафін за загальноприйнятими методиками. Зрізи фарбували гематоксиліном та еозином [19]. Огляд мікропрепаратів проводили під мікроскопом Mikros 400. Мікрофотографування мікроскопічних зображень виконували цифровим фотоапаратом Nikon Cool Pix 4500.

Результати й обговорення. При гістологічному дослідженні печінки контрольної групи тварин ми спостерігали, що часточкова будова органа була збереженою. Добре візуалізувалась центральна вена та синусоїди, їх просвіти були вільними від еритроцитів. Макрофагальна активність була мінімальною. Структура клітин була однорідною, усі гепатоцити містили ядра, були організованими у балкові структури. Судини портальних трактів мали звичайну будову та мізерну лімфогістіоцитарну інфільтрацію. Жовчні протоки не візуалізувались (рис. 1).

При токсичному ураженні печінки на 4-ту добу ми спостерігали, що структура печінкової часточки була збереженою частково. Центральні вени розширювались незначно та не містили еритроцитів. Синусоїди не візуалізувались. Переважна більшість гепатоцитів мала різну форму та насиченість цитоплазми. Контури клітин були стертими. Багато клітин не містили ядер або вони перебували у стадії каріопікнозу або каріорексису (рис. 2), що свідчить про переважання дистрофічно-некротичних змін над регенераторними. Судини портальних трактів розширювались незначно, периваскулярний набряк та лімфогістіоцитарна інфільтрація перипортальних трактів були мінімальними.

На 7-му добу експерименту ми спостерігали, що структурні зміни гепатоцитів поєднувались із розширенням синусоїдальних просторів та накопиченням у них еритроцитів (рис. 3).

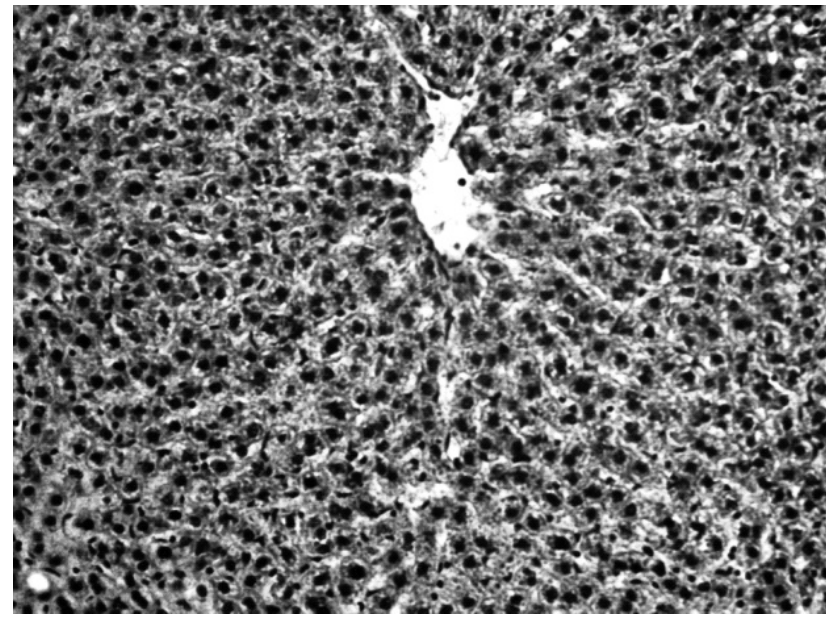

Рис. 1. Гістологічна структура печінкової часточки у контрольної тварини. Забарвлення гематоксиліном та еозином. $\times 180$.

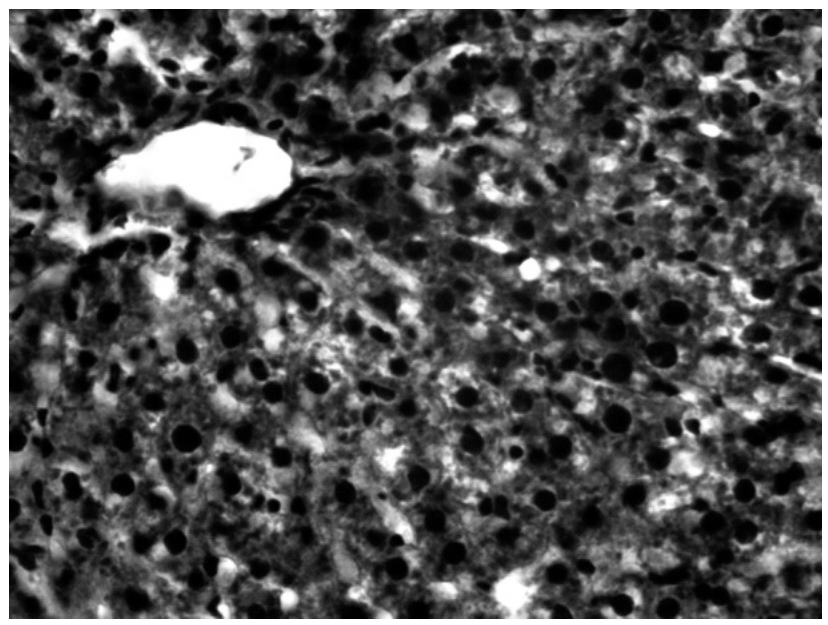

Рис. 2. Гістологічна структура печінкової часточки тварини при моделюванні $\mathrm{CCl}_{4}$ гепатиту, 4-та доба експерименту.

Забарвлення гематоксиліном та еозином. × 200.

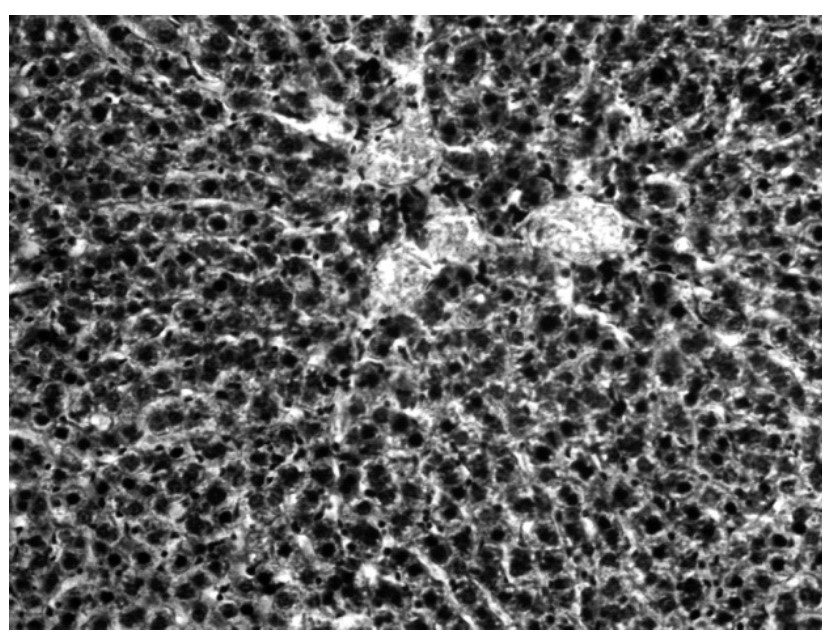

Pис. 3. Гістологічна структура печінкової часточки тварини при моделюванні $\mathrm{CCl}_{4}$ гепатиту, 7-ма доба експерименту. Забарвлення гематоксиліном та еозином. $\times 180$.

ISSN 2312-0967. Фармацевтичний часопис. 2015. № 1 
Фармакологічні дослідження біологічно активних речовин

Pharmacological researches of biologically active substances

Також привертало увагу збільшення кількості макрофагів у їх структурах. У клітинах середньої третини печінкової часточки переважали дистрофічно-некротичні зміни. Судини портальних трактів розширювались, були повнокровними, мав місце незначний периваскулярний набряк, проте перипортальна лімфогістіоцитарна інфільтрація залишалась помірною. Жовчні протоки не розширювались, проте мали місце внутрішньоклітинні холестази (рис. 3).

Гістологічна структура печінки тварини з $\mathrm{CCl}_{4}$ гепатитом на фоні корекції корвітином змінювалась наступним чином. На 4-ту добу експерименту часточкова структура органу була збереженою. Центральні вени помірно розширювались, не містили еритроцити. Центролобулярні гепатоцити були збереженими (рис. 4).

Синусоїди добре візуалізувались і містили незначну кількість макрофагів. Балкова організація гепатоцитів була збереженою. В клітинах спостерігались помірні дистрофічні зміни, особливо в середній третині часточки, проте більшість гепатоцитів містили ядра. Лімфогістіоцитарна інфільтрація перипортальних полів була мінімальною. Часточкові жовчні протоки розширувались, проте явищ внутрішньоклітинного холестазу не спостерігалось (рис. 4).

На 7-му добу експерименту ми спостерігали, що структура печінкової часточки була збереженою, проте привертало увагу накопичення еритроцитів у центральних венах і помірно розширених синусоїдальних просторах. В окремих випадках мали місце поодинокі повнокровні судини портальних трактів та невелика кількість еритроцитів у перипортальних синусоїдах. Також у окремих часточках мали місце внутрішньоклітинні холестази. Лімфогістіоцитарна

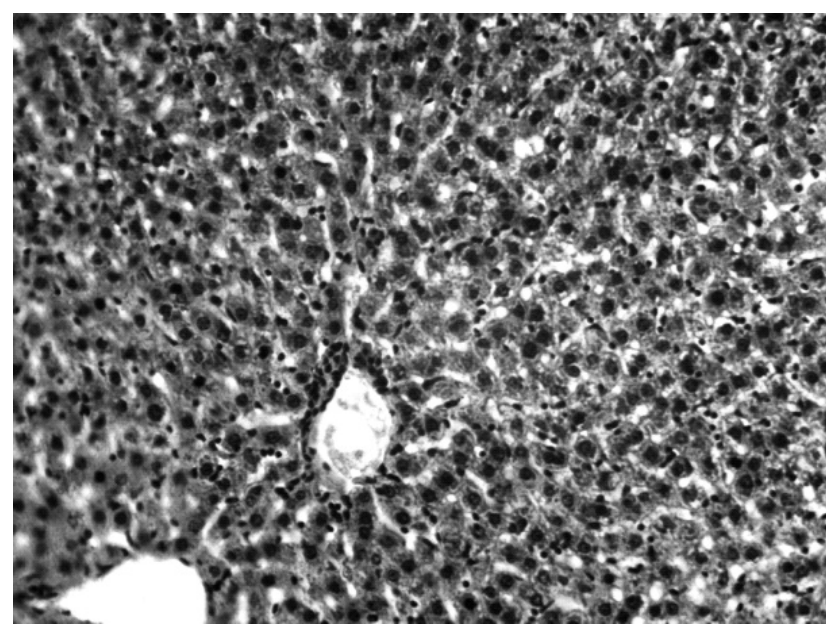

Рис. 4. Гістологічна структура печінкової часточки тварини при моделюванні $\mathrm{CCl}_{4}$ гепатиту та корекції корвітином, 4-та доба експерименту Забарвлення гематоксиліном та еозином. $\times 180$. інфільтрація перипортальних полів була мінімальною (рис. 5).

При гістологічному дослідженні печінки у тварин із $\mathrm{CCl}_{4}$ гепатитом та корекцією ГЕЛШ на 4-ту добу експерименту ми спостерігали, що структура часточки була збереженою частково. Центральні вени розширювались та були повнокровними, синусоїди в більшості візуалізувались добре, проте містили незначну кількість еритроцитів та макрофагів (рис. 6).

Балкова організація гепатоцитів в більшості була збереженою. Структурно клітини мали різну форму, в них спостерігалась гіаліново-крапельна та гідропічна білкова дистрофія, проте у цих клітин чітко візуалізувались ядра. Проте на 7-му добу експерименту структурна організація значно покращувалась порівняно із 4-ю добою (рис. 6).

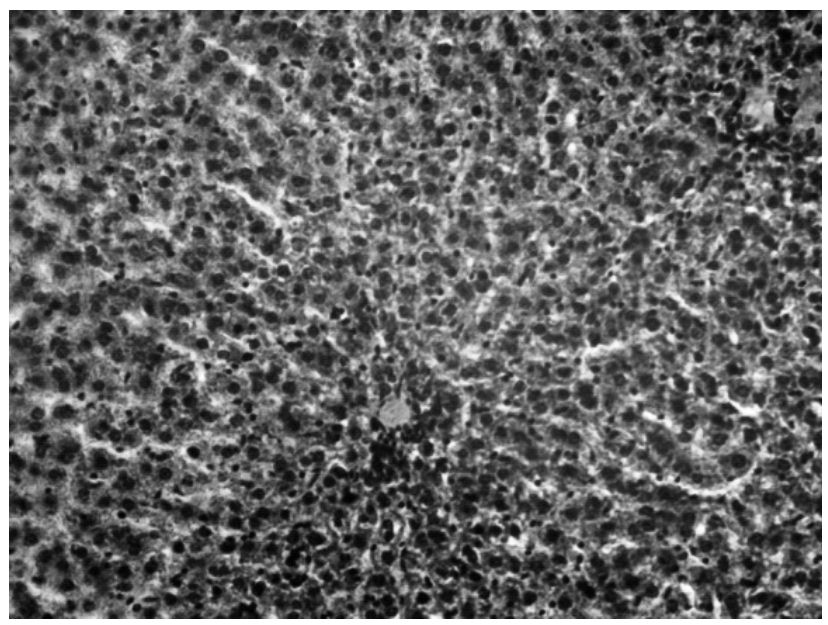

Рис. 5. Гістологічна структура печінкової часточки тварини при моделюванні $\mathrm{CCl}_{4}$ гепатиту та корекції корвітином. Експериментальне дослідження на 7-му добу. Забарвлення гематоксиліном та еозином.×180.

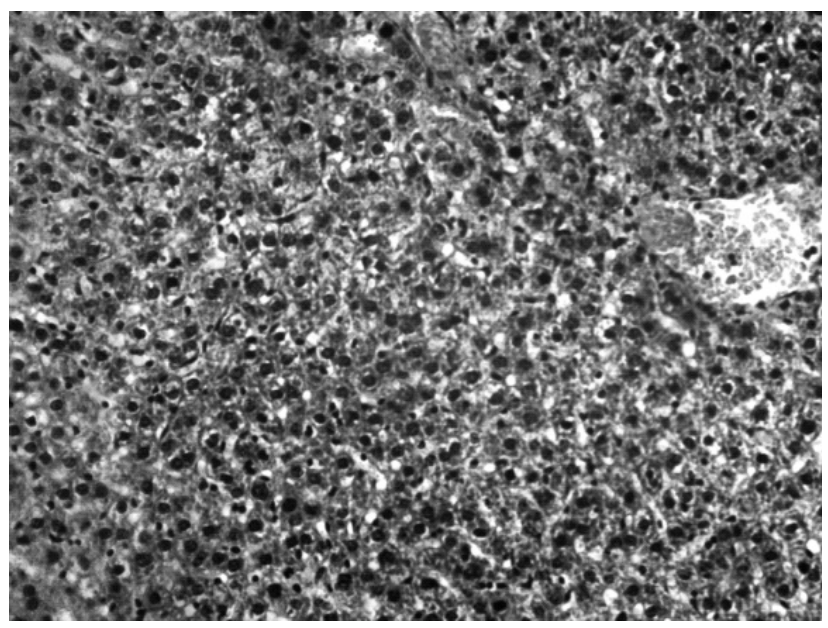

Рис. 6. Гістологічна структура печінкової часточки тварини при моделюванні $\mathrm{CCl}_{4}$ гепатиту та корекції ГЕЛШ, 4-та доба експерименту. Забарвлення гематоксиліном та еозином. $\times 180$.

ISSN 2312-0967. Pharmaceutical review. 2015. № 1 
У перипортальних полях структура клітин відновлювалась, гепатоцити мали однорідну цитоплазму, чітко виражені ядра та синусоїдні капіляри. Судини перипортальних трактів були розширеними та не містили еритроцитів (рис. 7).

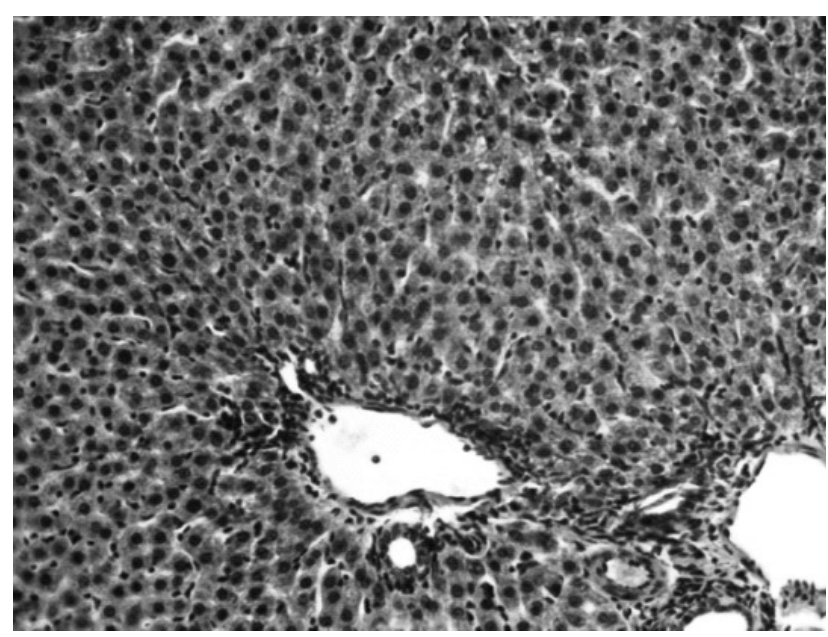

Рис. 7. Гістологічна структура печінкової часточки тварини при моделюванні $\mathrm{CCl}_{4}$ гепатиту та корекції

ГЕЛШ, 7-ма доба експерименту. Забарвлення гематоксиліном та еозином. × 180 .

Висновки. Таким чином, корекція тетрахлорметанового гепатиту препаратом порівняння приводить до покращення структурної організації печінки, яка відображається у відновлені часточкової будови, зменшенні дистрофічнонекротичних змін гепатоцитів та частковому усуненні внутрішньоклітинних холестазів. При застосуванні ГЕЛШ часточкова структура печінки відновлюється найбільше, зменшуються дистро-

\section{Література}

1. Вивчення гепатозахисної активності поліфенольних комплексів із винограду сортів «Каберне» та «Ркацителі» в умовах гострого токсичного гепатиту у щурів / Л. М. Вороніна, А. Л. Загайко, О. В. Файзулін [та ін.] // Український біофармацевтичний журнал. 2009. - T. 1, № 3. - С. 44-46.

2. Вивчення мембраностабілізувальної активності рослинного лікарського засобу / Л. І. Шульга, О. А. Щербак, Л. М. Малоштан [та ін.] // Фармацевтичний часопис. - 2011. - № 3(19). - С. 99-101.

3. Дроговоз С. М. Современные подходы к терапии заболеваний гепатобилиарной системы / С. М. Дроговоз, Е. Г. Щекина, А. Ушакова // Провизор. - 2008. - № 8. - C. 19-22.

4. Лісничук Н. Є. Дослідження параметрів вільнорадикального окиснення та стан антиоксидантної системи білих щурів з експериментальним токсичним ураженням печінки / Н. Є. Лісничук // Вісник проблем біології і медицини. - 2007. - Вип. 2. - С. 83-88.

5. Muriel P. Beneficial drugs for liver diseases / P. Muriel,
Периваскулярні простори незначно інфільтрувались лімфо-гістіоцитарними інфільтратами. Жовчні капіляри були помірно розширеними (рис. 8), внутрішньоклітинний холестаз не спостерігався.

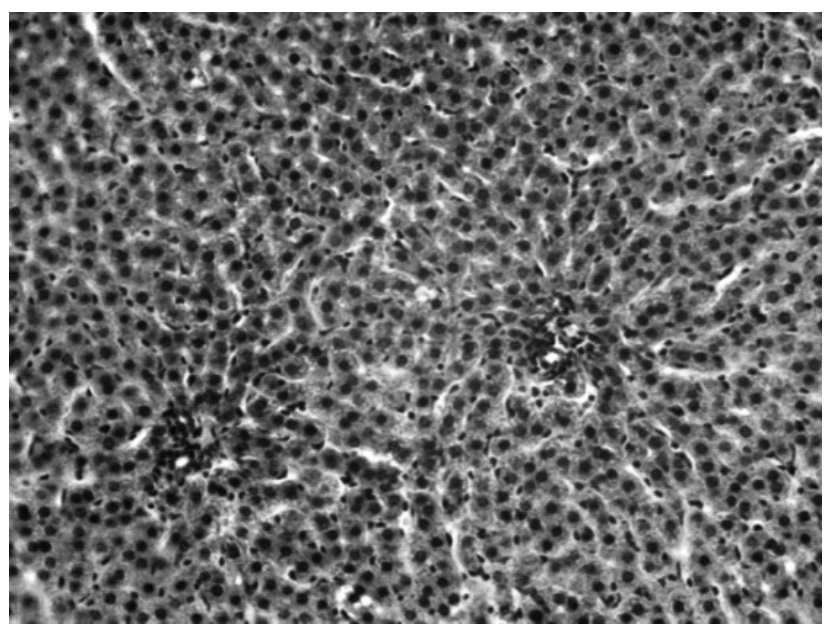

Рис. 8. Гістологічна структура печінкової часточки тварини при моделюванні $\mathrm{CCl}_{4}$ гепатиту та корекції

ГЕЛШ, 7-ма доба експерименту. Забарвлення гематоксиліном та еозином. × 180 .

фічно-некротичні зміни в клітинах, проте залишаються незначні розлади кровообігу.

Отже, проведені нами фармакологічні, біохімічні та гістологічні дослідження підтвердили гепатопротекторні, антиоксидантні та мембранопротекторні властивості густого екстракту 3 листя шовковиці чорної, що дозволяє рекомендувати подальші дослідження і створення нових лікарських засобів на його основі.

Y. Rivera-Espinoza // J. Appl. Toxicol. - 2008. - Vol. 28, № 2 - P. 93-103.

6. Identification of hepatoprotective flavonolignans from silymarin / S. J. Polyak, C. Morishima, V. Lohmann [et al.] // Proc. Natl. Acad. Sci .U S A. - 2010. - Vol. 107, № 13 P. 95-99.

7. Грицик А. Р. Пошук лікарських рослин, які застосовуються для лікування захворювань гепатобіліарної системи / А. Р. Грицик, Н. М. Гузьо, Н. М. Посацька // Фітотерапія. Часопис. - 2007. - № 2. - С. 47-51.

8. Препараты растительного происхождения в лечении гепатита C / В. Т. Ивашкин, М. А. Морозова, М. В. Маевская [и др.] // Российский журнал гастроэнтерологии, гепатологии, колопроктологии. - 2009. T. 19, № 3. - C. 70-75.

9. Arulkumaran K. S. G. Cassia roxburghil seeds protect liver against toxic effects of ethanol and carbontetrachloride in rats / K. S. G. Arulkumaran, A. Rajasekaran, R. Ramasamy // Int. J. Pharm. Tech. Res. - 2007. - Vol. 1(2). - P. 246273.

ISSN 2312-0967. Фармацевтичний часопис. 2015. № 1 
Фармакологічні дослідження біологічно активних речовин

Pharmacological researches of biologically active substances

10. The inactivation of lipid peroxide radical by quercetin. A theoretical insight / S. G. Chido, M. Leopoldini, N. Russo [et al.] // J. Pharmacol, Exp. Ther. - 2006. - Vol. 319, № 2. - P. 703-709.

11. Вітенко В. А. Використання Morus alba L. i Morus nigra L. у традиційній та нетрадиційній медицині / В. А. Вітенко // Науковий вісник НЛтУ України. - 2010. - Вип. 20.13. - С. 33-39.

12. Цуркан О. О. Вивчення амінокислотного складу листя та кори шовковиці білої (Morus alba L.) і шовковиці чорної (Morus nigra L.) / О. О. Цуркан, Т. В. Ковальчук, О. В. Гергель // Біологія та фармація. - 2010. - № 3. - С. 56-58.

13. Ляхович Р. М. Вплив комбінованого застосування тіотриазоліну та внутрішньошлункової оксигенації на перебіг гострого тетрахлорметанового гепатиту / Р. М. Ляхович, В.В.Гнатів, А. А. Гудима // Актуальные проблемы транспортной медицины. - 2011. - № 1(23). - 135-138.

14. Яковлєва Л. В. Скринінгове дослідження гепатозахисної активності капсул "Гепафісан" в умовах гострого гепатиту у щурів, викликаного тетрахлорметаном / Л. В. Яковлєва, О.В.Геруш, О.Б.Леницька // Доклінічні дослідження. - 2011. - Т. 15, № 1. - С. 61-64.

15. Медвідь І. І. Вплив густого екстракту з листя чорної шовковиці на вільнорадикальні процеси в організмі щурів, уражених тетрахлорметаном / І. І. Медвідь, Л. С. Фіра // Здобутки клінічної та експериментальної медицини. - 2010. - № 2(13). - С. 66-69.

16. Медвідь І. І. Вивчення гепатопротекторної та антиоксидантної властивостей густого екстракту з листя шовковиці чорної. Інформаційний лист / І. І. Медвідь, Л. С. Фіра, П. Г. Лихацький / Інформаційний бюлетень. Додаток до «Журналу Академії медичних наук України». - 2011. - Вип. 28. - С. 163-165.

17. Медвідь І. І. Показники антиоксидантної системи щурів, уражених тетрахлорметаном, після застосування екстракту з листя шовковиці / І. І. Медвідь, Л. С. Фіра, Н. І. Бурмас // Медична хімія. - 2011. Т. 13, № 4(49). - С. 54-56.

18. Рыболовлев Ю. Р. Дозирование веществ для млекопитающих по константам биологической активности / Ю. Р. Рыболовлев, Р. С. Рыболовлев // Доклады АН СССР. - 1979. - Т. 247, № 6. - С. 1513-1516.

19. Гистология / [Под. ред. Ю. И. Афанасьева, Н. А. Юриной]. - М. : Медицина, 1999.- 744 с.

\title{
ИЗМЕНЕНИЯ ГИСТОЛОГИЧЕСКОГО СТРОЕНИЯ ПЕЧЕНИ КРЫС В УСЛОВИЯХ ТЕТРАХЛОРМЕТАНОВОГО ГЕПАТИТА И КОРРЕКЦИИ ГУСТЫМ ЭКСТРАКТОМ ИЗ ЛИСТЬЯ ШЕЛКОВИЦЫ ЧЕРНОЙ
}

\section{И. И. Герасимец}

Тернопольский государственный медицинский университет имениИ. Я. Горбачевского

Резюме: проведено гистологическое изучение влияния густого экстракта из листьев шелковицы черной на течение свободнорадикальных процессов в печени крыс, пораженных тетрахлорметаном. Установлено, что под влиянием исследуемого фармакологического препарата уменьшаются нарушения гистологической структуры печени, которые возникают при остром тетрахлорметановом гепатите.

Ключевые слова: густой экстракт, листья шелковицы черной, гепатопротекторные свойства, тетрахлорметановый гепатит.

\section{CHANGES OF THE RAT'S LIVER HISTOLOGICAL STRUCTURE UNDER THE CONDITIONS OF TETRACHLOROMETHANE HEPATITIS AND CORRECTION BY THICK EXTRACT OF BLACK MULBERRY LEAVES}

\section{I. Herasymets}

\author{
Ternopil State Medical University by I. Ya. Horbachevsky
}

Summary: a histological study of the thick extract of black mulberry leaves influence on the course of free radical processes in the liver of rats affected with tetrachloromethane was conducted. It is established that under the influence of investigational pharmacological agent violations of the liver histological structure that occur at acute tetrachloromethane hepatitis are reduced.

Key words: thick extract, black mulberry leaves, hepatoprotective properties, tetrachloromethane hepatitis. 